\title{
Agromyces italicus sp. nov., Agromyces humatus sp. nov. and Agromyces lapidis sp. nov., isolated from Roman catacombs
}

\author{
Valme Jurado, ${ }^{1}$ Ingrid Groth, ${ }^{2}$ Juan M. Gonzalez, ${ }^{1}$ Leonila Laiz, ${ }^{1}$ \\ Barbara Schuetze $^{2}$ and Cesareo Saiz-Jimenez ${ }^{1}$ \\ ${ }^{1}$ Instituto de Recursos Naturales y Agrobiologia, CSIC, Apartado 1052, E-41080 Sevilla, Spain \\ ${ }^{2}$ Hans-Knöll-Institute for Natural Products Research, Member of the Leibniz Association, \\ D-07745 Jena, Germany
}

\begin{abstract}
A polyphasic study was carried out to clarify the taxonomic positions of three Gram-positive isolates from the Catacombs of Domitilla, Rome (Italy). 16S rRNA gene sequence comparisons placed these strains within the genus Agromyces. The morphological and chemotaxonomic characteristics of these isolates were consistent with the description of the genus Agromyces. The three isolates could be readily distinguished from one another and from representatives of all Agromyces species with validly published names by a broad range of phenotypic characteristics and DNA-DNA relatedness studies. Therefore, these isolates are proposed to represent three novel species of the genus Agromyces, Agromyces italicus sp. nov. (type strain $\mathrm{CD} 1^{\top}=\mathrm{HKI}$ $0325^{\top}=\mathrm{DSM} 16388^{\top}=$ NCIMB $14011^{\top}$ ), Agromyces humatus sp. nov. (type strain $\mathrm{CD}^{\top}=\mathrm{HKI}$ $0327^{\top}=\mathrm{DSM} 16389^{\top}=$ NCIMB $14012^{\top}$ ) and Agromyces lapidis sp. nov. (type strain CD55 ${ }^{\top}$ $=\mathrm{HKI} 0324^{\top}=\mathrm{DSM} 16390^{\top}=$ NCIMB $\left.14013^{\top}\right)$.
\end{abstract}

Strains of the genus Agromyces are common inhabitants of different soils ranging from fertile meadows to deserts [Agromyces ramosus Gledhill and Casida 1969, Agromyces cerinus subsp. cerinus Zgurskaya et al. 1992, Agromyces cerinus subsp. nitratus Zgurskaya et al. 1992, Agromyces fucosus Zgurskaya et al. 1992 emend. Ortiz-Martinez et al. 2004, Agromyces hippuratus (Zgurskaya et al. 1992) OrtizMartinez et al., 2004, Agromyces mediolanus Suzuki et al. 1996 and Agromyces aurantiacus $\mathrm{Li}$ et al. 2003]. The rhizosphere of plants harbours a wide diversity of these organisms, as has been shown by Takeuchi \& Hatano (2001) with the description of three species, Agromyces bracchium, Agromyces luteolus and Agromyces rhizospherae, from mangrove rhizosphere soil. Dorofeeva et al. (2003) isolated Agromyces albus from the leaves and inflorescences of members of the Primulaceae, while Agromyces ulmi was isolated from the decayed stump of an elm tree, Ulmus nigra (Rivas et al., 2004). Recently, two novel species of this genus, Agromyces salentinus and Agromyces neolithicus, have been isolated from the Grotta dei Cervi, a cave in southern Italy with singular neolithic rock art paintings (Jurado et al., 2005).

Published online ahead of print on 5 November 2004 as DOI 10.1099/ ijs.0.63414-0.

The GenBank/EMBL/DDBJ accession numbers for the 16S rRNA gene sequences of strains $\mathrm{CD}^{\top}, \mathrm{CD}^{\top}$ and $\mathrm{CD}^{\top} 5^{\top}$ are $\mathrm{AY} 618215$, AY618216 and AY618217, respectively.
Strains $\mathrm{CD} 1^{\mathrm{T}}$ and $\mathrm{CD}^{\mathrm{T}}$ were obtained from the wall of a tomb located in the Little Apostle cubicle, Domitilla Catacombs, Rome, Italy (Sanchez-Moral et al., 2004). Strain $\mathrm{CD} 55^{\mathrm{T}}$ was isolated by touching the stone wall of a tomb (first arcosolium on the left side behind the entrance of Domitilla Catacombs) with a sterile cotton swab and suspending the attached bacteria in $1: 10$ diluted organic medium 79 (OM79) (Prauser \& Falta, 1968; Jurado et al., 2005). The strains were isolated on nutrient agar (Difco) or, in the case of strain $\mathrm{CD} 55^{\mathrm{T}}$, on peptone/yeast extract/brain heart infusion agar (Yokota et al., 1993), using a standard dilution plate procedure.

All the methods used in this study have been recently described by Jurado et al. (2005). Range of $\mathrm{pH}$ for growth was established using liquid OM79 medium adjusted to initial $\mathrm{pH}$ values between 4 and 11 with either $1 \mathrm{M} \mathrm{HCl}$ or $20 \%(\mathrm{w} / \mathrm{v}) \mathrm{Na}_{2} \mathrm{CO}_{3}$ solution and incubated at $28{ }^{\circ} \mathrm{C}$ for up to 10 days. The following type strains were used as references for comparative studies: A. albus VKM Ac$1800^{\mathrm{T}}$, A. cerinus subsp. cerinus IMET $11525^{\mathrm{T}}$, A. fucosus IMET $11529^{\mathrm{T}}$, A. mediolanus VKM Ac- $1388^{\mathrm{T}}$, A. neolithicus DSM $16197^{\mathrm{T}}$, A. ramosus IMET $11027^{\mathrm{T}}$ and A. salentinus DSM $16198^{\mathrm{T}}$. Morphological and physiological traits are summarized in the species descriptions and Table 1.

Differences referring to the compositions of whole-cell sugars, menaquinones and polar lipids are shown in Table 2. Cell-wall amino acids in strains $\mathrm{CD}^{\mathrm{T}}, \mathrm{CD}^{\mathrm{T}}$ and $\mathrm{CD} 55^{\mathrm{T}}$ 
Table 1. Characteristics that differentiate strains $C D 1^{\top}, C D 5^{\top}$ and $C D 55^{\top}$ and their closest relatives within the genus Agromyces

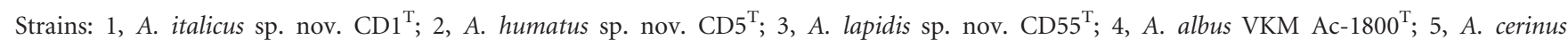
subsp. cerinus IMET $11525^{\mathrm{T}}$; 6, A. fucosus IMET $11529^{\mathrm{T}}$; 7, A. mediolanus VKM Ac-1388 ${ }^{\mathrm{T}}$; 8, A. neolithicus DSM 16197 ${ }^{\mathrm{T}}$; 9, A. ramosus IMET $11027^{\mathrm{T}}$; 10, A. salentinus DSM $16198^{\mathrm{T}}$. Data for A. cerinus subsp. cerinus and A. ramosus were taken from Groth et al. (1996). -, Negative; +, positive; $(+)$ weakly positive; V, variable; ND, not determined. Strains $\mathrm{CD}^{\mathrm{T}}, \mathrm{CD} 5^{\mathrm{T}}$ and $\mathrm{CD} 55^{\mathrm{T}}$ share the following properties. They produce acid from starch, arbutin, D-fructose, glycogen, maltose, D-mannose, but not from adonitol, D-arabitol, L-arabitol, dulcitol, erythritol, D-fucose, gluconate, 2-ketogluconate, 5-ketogluconate, $\beta$-gentiobiose, inositol, D-lyxose, melibiose, melezitose, sorbitol, L-sorbose; D-tagatose, L-xylose, methyl $\beta$-xyloside or xylitol. They produce alkaline phosphatase, esterase (C1), esterase lipase (C8), leucine arylamidase, valine arylamidase, cystine arylamidase, acid phosphatase, naphthol-AS-BI-phosphohydrolase, $\alpha$-glucosidase and $\beta$-glucosidase, but not $\alpha$ galactosidase, $N$-acetyl- $\beta$-glucosaminidase, lipase (C14), trypsin or $\alpha$-fucosidase. They are sensitive to chloramphenicol (30 $\mu \mathrm{g}$ ), imipenem $(10 \mu \mathrm{g})$, ofloxacin $(10 \mu \mathrm{g})$, oxytetracycline hydrochloride $(30 \mu \mathrm{g})$, rifampicin $(5 \mu \mathrm{g})$ and vancomycin hydrochloride (30 $\mu \mathrm{g})$, but not to kanamycin $(30 \mu \mathrm{g})$, lincomycin $(2 \mu \mathrm{g})$, norfloxacin $(10 \mu \mathrm{g})$ or sulfonamide $(200 \mu \mathrm{g})$. They hydrolyse aesculin and starch, but not adenine or Tween 80. Voges-Proskauer, methyl red and indole tests give negative results. They are positive for $\mathrm{H}_{2} \mathrm{~S}$ production.

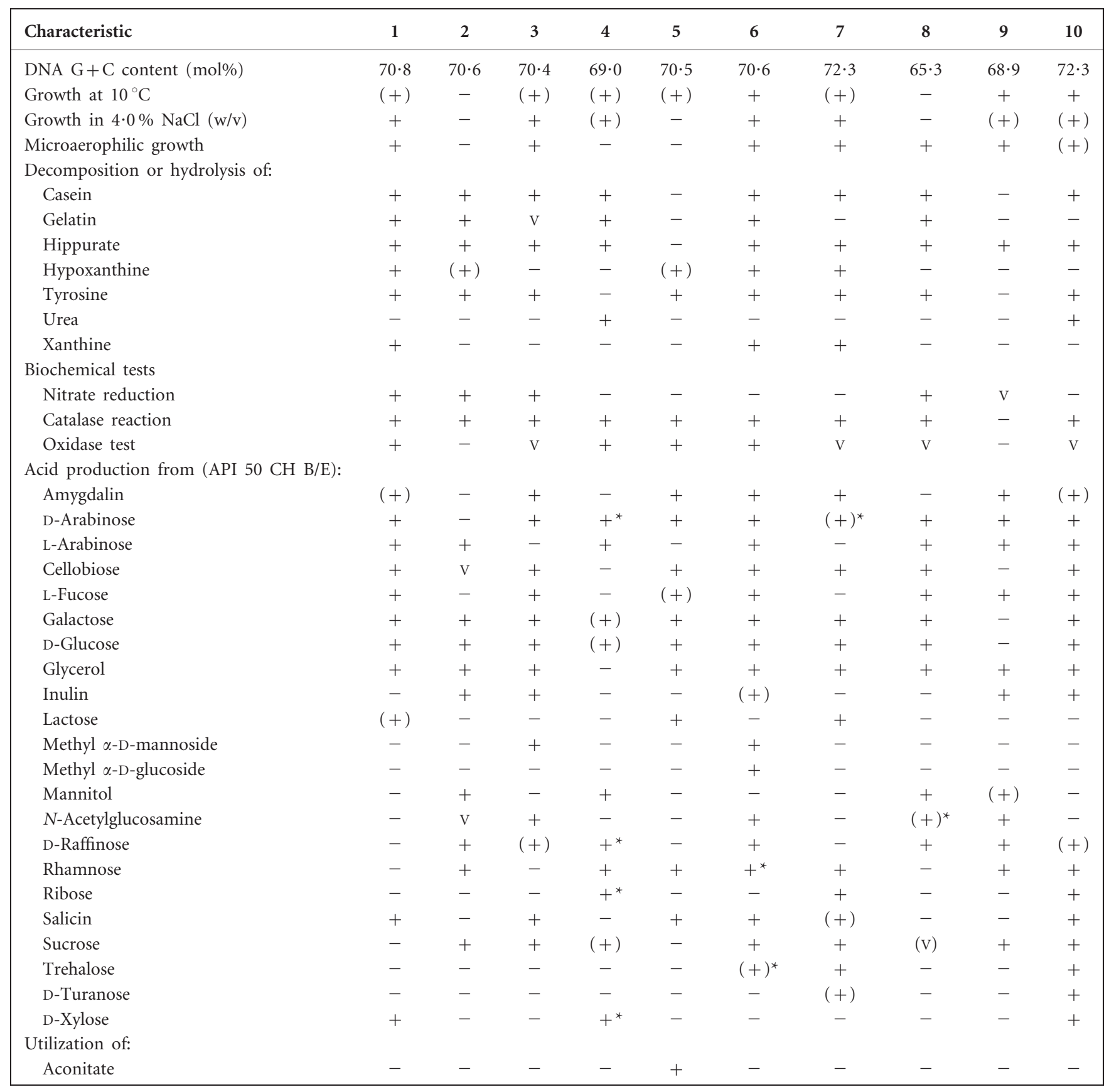


Table 1. cont.

\begin{tabular}{|c|c|c|c|c|c|c|c|c|c|c|}
\hline Characteristic & 1 & 2 & 3 & 4 & 5 & 6 & 7 & 8 & 9 & 10 \\
\hline Citrate & - & - & - & - & + & - & - & - & - & - \\
\hline Malate & - & + & - & + & + & - & - & - & + & - \\
\hline \multicolumn{11}{|l|}{ Enzyme assays (API ZYM): } \\
\hline$\alpha$-Chymotrypsin & - & - & + & - & - & - & - & + & - & - \\
\hline$\beta$-Glucuronidase & - & + & - & - & - & - & - & + & - & - \\
\hline$N$-Acetyl- $\beta$-glucosaminidase & - & - & - & + & - & + & + & + & - & + \\
\hline$\alpha$-Mannosidase & - & + & - & - & - & - & - & + & - & - \\
\hline \multicolumn{11}{|l|}{ Antibiotic susceptibility: } \\
\hline Ampicillin $(10 \mu \mathrm{g})$ & + & + & + & + & + & - & + & + & + & + \\
\hline Norfloxacin $(10 \mu \mathrm{g})$ & - & - & - & - & - & - & - & + & - & + \\
\hline Novobiocin $(5 \mu \mathrm{g})$ & + & + & + & + & + & + & - & + & - & + \\
\hline Penicillin G (10 IU) & + & - & + & - & - & - & - & + & + & + \\
\hline Polymyxin B (300 IU) & - & + & - & + & $\mathrm{V}$ & - & - & + & + & + \\
\hline Streptomycin sulfate $(10 \mu \mathrm{g})$ & - & + & - & + & + & + & - & - & + & + \\
\hline Sulfonamide $(200 \mu \mathrm{g})$ & - & - & - & - & - & - & - & - & - & + \\
\hline
\end{tabular}

${ }^{\star}$ Delayed response.

were diaminobutyric acid, glycine, glutamic acid and alanine. Acyl type for these three strains was acetyl. The predominant fatty acids of strains $\mathrm{CD} 1^{\mathrm{T}}, \mathrm{CD} 5^{\mathrm{T}}$ and $\mathrm{CD} 55^{\mathrm{T}}$ were anteiso- $\mathrm{C}_{15: 0}(50 \cdot 9,41 \cdot 5$ and $48 \cdot 1 \%$, respectively), anteiso- $\mathrm{C}_{17: 0}(15 \cdot 3,34 \cdot 0$ and $13 \cdot 0 \%)$, iso- $\mathrm{C}_{16: 0}(14 \cdot 7,15 \cdot 5$ and $16 \cdot 5 \%)$, iso- $\mathrm{C}_{15: 0}(14 \cdot 2,5 \cdot 4$ and $10 \cdot 5 \%)$ and $\mathrm{C}_{16: 0}$ $(1 \cdot 7,1 \cdot 3$ and $5 \cdot 9 \%)$.

Sequence comparisons of $16 \mathrm{~S}$ rRNA genes from strains $\mathrm{CD} 1^{\mathrm{T}}, \mathrm{CD}^{\mathrm{T}}$ and $\mathrm{CD} 55^{\mathrm{T}}$ showed a close phylogenetic relationship to $A$. ramosus, $A$. cerinus subsp. cerinus, $A$. salentinus, A. neolithicus, A. albus, A. mediolanus and $A$. fucosus with percentages of similarity ranging from 94 to $98 \%$. Strains $\mathrm{CD}^{\mathrm{T}}$ and $\mathrm{CD} 55^{\mathrm{T}}$ showed high similarity
(97\%). The recently described species A. salentinus (Jurado et al., 2005) was highly related to strains $\mathrm{CD}^{\mathrm{T}}$ and $\mathrm{CD}^{\mathrm{T}} 5^{\mathrm{T}}$ with $97 \%$ similarity. A. neolithicus was the closest relative to strain $\mathrm{CD}^{\mathrm{T}}(98 \%)$. A phylogenetic tree generated by the neighbour-joining method showing the relationships between members of the genus Agromyces and the three novel isolates, $\mathrm{CD}^{\mathrm{T}}, \mathrm{CD}^{\mathrm{T}}$ and $\mathrm{CD} 55^{\mathrm{T}}$, is shown in Fig. 1.

The DNA G $+\mathrm{C}$ contents of strains $\mathrm{CD} 1^{\mathrm{T}}, \mathrm{CD} 5^{\mathrm{T}}$ and $\mathrm{CD} 55^{\mathrm{T}}$ were $70 \cdot 8,70 \cdot 6$ and $70 \cdot 4 \mathrm{~mol} \%$, respectively. DNA-DNA relatedness studies showed significant differences between the three isolates as well as with their closest phylogenetic neighbours. In all cases, differences in melting temperatures were $>7 \cdot 7^{\circ} \mathrm{C}$ (roughly $<51 \%$ DNA-DNA relatedness;

Table 2. Chemotaxonomic characteristics of strains $\mathrm{CD} 1^{\top}, \mathrm{CD} 5^{\top}$ and $\mathrm{CD} 55^{\top}$

Components are listed in decreasing order of abundance.

\begin{tabular}{|lccc|}
\hline Characteristic & Strain CD1 $^{\mathrm{T}}$ & Strain CD5 $^{\mathrm{T}}$ & Strain CD55 $^{\mathrm{T}}$ \\
\hline Whole-cell sugars & Gal, Rib, Glc, Man & Glc, Gal, Rha, Man & Glc, Gal, Man, Rib \\
Major menaquinones & 12,13 & 13,12 & 12,13 \\
Polar lipids $\dagger$ & DPG, PG, 2 PL, GL & DPG, PG, PL, 2 GL & DPG, PG, PL, 2 GL \\
\hline
\end{tabular}

${ }^{*} \mathrm{Gal}$, Galactose; Glc, glucose; Man, mannose; Rha, rhamnose; Rib, ribose.

$\nmid$ DPG, Diphosphatidylglycerol; GL, unknown glycolipid; PG, phosphatidylglycerol; PL, unknown phospholipid. 


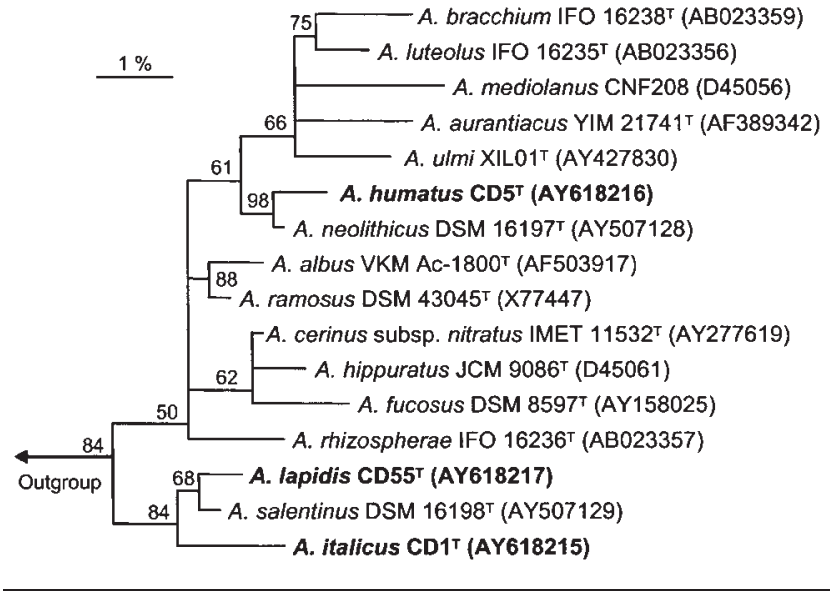

Fig. 1. Neighbour-joining phylogenetic tree showing the relationships between species of the genus Agromyces and isolates $\mathrm{CD}^{\top}, \mathrm{CD}^{\top}$ and $\mathrm{CD}^{\top} 5^{\top}$ based on $16 \mathrm{~S}$ rRNA gene sequences. Bar, $1 \%$ sequence divergence. The outgroup (not shown) was Corynebacterium sp. QSSC3-5 (AF170740).

Rosselló-Mora \& Amann, 2001), which is well above the $5{ }^{\circ} \mathrm{C}$ cut-off point recommended for the delineation of species (Stackebrandt \& Goebel, 1994).

The genotypic and phenotypic characteristics of strains $\mathrm{CD} 1^{\mathrm{T}}, \mathrm{CD}^{\mathrm{T}}$ and $\mathrm{CD} 55^{\mathrm{T}}$ are consistent with their classification in the genus Agromyces (Gledhill \& Casida, 1969; Zgurskaya et al., 1992). The isolates can be readily distinguished from representatives of Agromyces species with validly published names, and from one another, by a broad range of phenotypic properties (Table 1) and composition of whole-cell sugars (Table 2). DNA-DNA relatedness data support the above distinctions between strains $\mathrm{CD} 1^{\mathrm{T}}, \mathrm{CD} 5^{\mathrm{T}}$ and $\mathrm{CD} 55^{\mathrm{T}}$ and their closest relatives within the genus Agromyces. Based on the results of this polyphasic approach, we propose that the three studied isolates are classified within novel species of the genus Agromyces, Agromyces italicus sp. nov. (strain $\mathrm{CD}^{\mathrm{T}}$ ), Agromyces humatus sp. nov. (strain $\mathrm{CD}^{\mathrm{T}}$ ) and Agromyces lapidis sp. nov. (strain $\mathrm{CD} 55^{\mathrm{T}}$ ).

\section{Description of Agromyces italicus sp. nov.}

Agromyces italicus (i.ta'li.cus. L. masc. adj. italicus from Italy, the origin of the type strain).

Gram-positive, aerobic to microaerophilic actinomycete that forms branching hyphae (width $0 \cdot 4-0 \cdot 6 \mu \mathrm{m}$ ) which break up into irregular diphtheroid and rod-like, nonmotile fragments. Colonies are circular, convex, smooth and cream. Colony diameter is about $1 \mathrm{~mm}$. Growth occurs between 10 and $37^{\circ} \mathrm{C}$ (optimal growth at $28{ }^{\circ} \mathrm{C}$ ) and at $\mathrm{pH} 5-9 \cdot 5 . \mathrm{NaCl}$ is tolerated up to $4 \%$ (w/v), but not at $6 \%(\mathrm{w} / \mathrm{v})$. Phenotypic characteristics including antibiotic susceptibility and enzymic activities are reported in Table 1. Chemotaxonomic characteristics are reported in Table 2. Cell-wall amino acids are diaminobutyric acid, glycine, glutamic acid and alanine. Acyl type is acetyl. Predominant fatty acids are anteiso- $\mathrm{C}_{15: 0}$ and anteiso- $\mathrm{C}_{17: 0} ;$ mycolic acids are absent. $\mathrm{G}+\mathrm{C}$ content is $70 \cdot 8 \mathrm{~mol} \%$.

The type strain is $\mathrm{CD}^{\mathrm{T}}\left(=\mathrm{HKI} 0325^{\mathrm{T}}=\mathrm{DSM} 16388^{\mathrm{T}}=\right.$ NCIMB $14011^{\mathrm{T}}$ ), isolated from the wall of a tomb located in the Little Apostle cubicle, Domitilla Catacombs, Rome, Italy.

\section{Description of Agromyces humatus sp. nov.}

Agromyces humatus (hu.ma'tus. L. masc. part. adj. humatus buried).

Gram-positive, aerobic actinomycete that forms branching hyphae (width $0 \cdot 3-0.5 \mu \mathrm{m}$ ) which break up into irregular diphtheroid and rod-like, non-motile fragments. Colonies are circular, convex, smooth and yellow. Colony diameter is about $1 \mathrm{~mm}$. Growth occurs between 15 and $37^{\circ} \mathrm{C}$ (optimal growth at $28{ }^{\circ} \mathrm{C}$ ) and at $\mathrm{pH} 5-9 \cdot 5 . \mathrm{NaCl}$ is tolerated up to $2 \%(\mathrm{w} / \mathrm{v})$, but not at $4 \%(\mathrm{w} / \mathrm{v})$. Phenotypic characteristics including antibiotic susceptibility and enzymic activities are reported in Table 1. Chemotaxonomic characteristics are reported in Table 2. Cell-wall amino acids are diaminobutyric acid, glycine, glutamic acid and alanine. Acyl type is acetyl. Predominant fatty acids are anteiso- $\mathrm{C}_{15: 0}$ and anteiso- $\mathrm{C}_{17: 0}$; mycolic acids are absent. $\mathrm{G}+\mathrm{C}$ content is $70 \cdot 6 \mathrm{~mol} \%$.

The type strain is $\mathrm{CD}^{\mathrm{T}}\left(=\mathrm{HKI} 0327^{\mathrm{T}}=\mathrm{DSM} 16389^{\mathrm{T}}=\right.$ NCIMB $14012^{\mathrm{T}}$ ), isolated from the wall of a tomb located in the Little Apostle cubicle, Domitilla Catacombs, Rome, Italy.

\section{Description of Agromyces lapidis sp. nov.}

Agromyces lapidis (la.pi' dis. L. gen. n. lapidis of a stone).

Gram-positive, aerobic to microaerophilic actinomycete that forms branching hyphae (width $0.4-0.6 \mu \mathrm{m}$ ) which break up into irregular diphtheroid and rod-like, nonmotile fragments. Colonies are circular, convex, smooth and yellow. Colony diameter is about $1 \mathrm{~mm}$. Growth occurs between 10 and $37^{\circ} \mathrm{C}$ (optimal growth at $28^{\circ} \mathrm{C}$ ) and at $\mathrm{pH} 5-9 \cdot 5 . \mathrm{NaCl}$ is tolerated up to $4 \%(\mathrm{w} / \mathrm{v})$, but not at $6 \%$ $(\mathrm{w} / \mathrm{v})$. Phenotypic characteristics including antibiotic susceptibility and enzymic activities are reported in Table 1. Chemotaxonomic characteristics are reported in Table 2. Cell-wall amino acids are diaminobutyric acid, glycine, glutamic acid and alanine. Acyl type is acetyl. Predominant fatty acids are anteiso- $\mathrm{C}_{15: 0}$ and iso- $\mathrm{C}_{16: 0}$; mycolic acids are absent. $\mathrm{G}+\mathrm{C}$ content is $70 \cdot 4 \mathrm{~mol} \%$.

The type strain is $\mathrm{CD}^{\mathrm{T}} 5^{\mathrm{T}}\left(=\mathrm{HKI} 0324^{\mathrm{T}}=\mathrm{DSM} 16390^{\mathrm{T}}=\right.$ NCIMB $14013^{\mathrm{T}}$ ), isolated from a carved stone wall of the Domitilla Catacombs, Rome, Italy.

\section{Acknowledgements}

V.J. and L.L. are grateful to fellowships from the Spanish Ministry of Education and Science (MEC) I3P programme and J.M. G. to an MEC contract from the 'Ramón y Cajal' programme. This study was 
supported by project CATS (EVK4-CT2000-00028) and MEC project BTE2002-04492-C02-01. We thank Christiane Weigel, Carmen Schult and Renate Schön for their technical assistance.

\section{References}

Dorofeeva, L. V., Krausova, V. I., Evtushenko, L. I. \& Tiedje, J. M. (2003). Agromyces albus sp. nov., isolated from a plant (Androsace sp.). Int J Syst Evol Microbiol 53, 1435-1438.

Gledhill, W. E. \& Casida, L. E. (1969). Predominant catalase-negative soil bacteria. III. Agromyces, gen. nov., microorganisms intermediary to Actinomyces and Nocardia. Appl Microbiol 18, 340-349.

Groth, I., Schumann, P., Weiss, N., Martin, K. \& Rainey, F. A. (1996). Agrococcus jenensis gen. nov., sp. nov., a new genus of actinomycetes with diaminobutyric acid in the cell wall. Int $J$ Syst Bacteriol 46, 234-239.

Jurado, V., Groth, I., Gonzalez, J. M., Laiz, L. \& Saiz-Jimenez, C. (2005). Agromyces salentinus sp. nov. and Agromyces neolithicus sp. nov. Int J Syst Evol Microbiol 55, 153-157.

Li, W. J., Zhang, L. P., Xu, P., Cui, X. L., Xu, L. H., Zhang, Z., Schumann, P., Stackebrandt, E. \& Jiang, C. L. (2003). Agromyces aurantiacus sp. nov., isolated from a Chinese primeval forest. Int J Syst Evol Microbiol 53, 303-307.

Ortiz-Martinez, A., Gonzalez, J. M., Evtushenko, L. I., Jurado, V., Laiz, L., Groth, I. \& Saiz-Jimenez, C. (2004). Reclassification of Agromyces fucosus subsp. hippuratus as Agromyces hippuratus sp. nov., comb. nov. and emended description of Agromyces fucosus. Int J Syst Evol Microbiol 54, 1553-1556.

Prauser, H. \& Falta, R. (1968). Phagensensibilität, ZellwandZusammensetzung und Taxonomie von Actinomyceten. $Z$ Allg Mikrobiol 8, 39-46 (in German).

Rivas, R., Trujillo, M. E., Mateos, P. F., Martínez-Molina, E. \& Velázquez, E. (2004). Agromyces ulmi sp. nov., a xylanolytic bacterium isolated from Ulmus nigra in Spain. Int J Syst Evol Microbiol 54, 1987-1990.

Rosselló-Mora, R. \& Amann, R. (2001). The species concept for prokaryotes. FEMS Microbiol Rev 25, 39-67.

Sanchez-Moral, S., Luque, L., Cañaveras, J. C., Laiz, L., Jurado, V., Hermosin, B. \& Saiz-Jimenez, C. (2004). Bioinduced barium precipitation in St Callixtus and Domitilla catacombs. Ann Microbiol 54, $1-12$.

Stackebrandt, E. \& Goebel, B. M. (1994). Taxonomic note: a place for DNA-DNA reassociation and $16 \mathrm{~S}$ rRNA sequence analysis in the present species definition in bacteriology. Int J Syst Bacteriol 44, 846-849.

Suzuki, K., Sasaki, J., Uramoto, M., Nakase, T. \& Komagata, K. (1996). Agromyces mediolanus sp. nov., nom. rev., comb. nov, a species for "Corynebacterium mediolanum" Mamoli 1939 and for some aniline-assimilating bacteria which contain 2,4-diaminobutyric acid in the cell wall peptidoglycan. Int J Syst Bacteriol 46, 88-93.

Takeuchi, M. \& Hatano, K. (2001). Agromyces luteolus sp. nov., Agromyces rhizospherae sp. nov. and Agromyces bracchium sp. nov., from the mangrove rhizosphere. Int J Syst Evol Microbiol 51, 1529-1537.

Yokota, A., Takeuchi, M., Sakane, T. \& Weiss, N. (1993). Proposal of six new species of the genus Aureobacterium and transfer of Flavobacterium esteraromaticum Omelianski to the genus Aureobacterium as Aureobacterium esteraromaticum comb. nov. Int J Syst Bacteriol 43, 555-564.

Zgurskaya, H. I., Evtushenko, L. I., Akimov, V. N., Voyevoda, H. V., Dobrovolskaya, T. G., Lysak, L. V. \& Kalakoutskii, L. V. (1992). Emended description of the genus Agromyces and description of Agromyces cerinus subsp. cerinus sp. nov., subsp. nov., Agromyces cerinus subsp. nitratus sp. nov., subsp. nov., Agromyces fucosus subsp. fucosus sp. nov., subsp. nov., and Agromyces fucosus subsp. hippuratus sp. nov., subsp. nov. Int J Syst Bacteriol 42, 635-641. 